Niepełnosprawność. Dyskursy pedagogiki specjalnej

\title{
Organizacyjne (re)konstruowanie pojęcia niepełnosprawności w środowisku osób uprawiających sport
}

Niniejszy artykuł jest oparty na studium przypadku przeprowadzonym w jednej z organizacji zrzeszających sportowców (klubie sportowym), w której obserwowano interakcje pomiędzy osobą z dysfunkcjami ciała a jej pełnosprawnymi kolegami. Początkowym celem badań było zrozumienie i opis problemów, z którymi spotykają się sportowcy z niepełnosprawnościami, działający w społecznym, organizacyjnym i fizycznym otoczeniu, które nie było zaprojektowane dla osób niepełnosprawnych. Jednak w trakcie badań wyłoniły się dodatkowe kwestie. W związku z tym głównym odkryciem było to, że bycie niepełnosprawnym wydaje się społecznie i organizacyjnie skonstruowane jeszcze zanim stanie się biologiczną czy fizyczną ułomnością. Ten właśnie organizacyjny proces, przez który „bycie osobą z dysfunkcjami ciała” jest powoli i rutynowo konstruowany, został opisany w niniejszym artykule.

Słowa kluczowe: niepełnosprawność, sport, społeczne konstruowanie znaczeń, teoria ugruntowana

\section{Organizational (re)construction of a disability concept within social, organizational and physical environment of people practicing sport}

The article is based on a case study conducted in one of the sportsmen's organizations (in a sports club), where interactions between a person with body dysfunctions and her able - bodied colleagues were observed. The initial aim of the study was to understand and describe the problems experienced by sportsmen with disabilities, functioning within social, organizational and physical environment, which was not designed to meet the needs of the disabled. However, within the course of a study some additional matters have been raised. Hence, the main finding was that being a disabled person seems socially and organizationally constructed even before it becomes a biological or physical handicap. The paper gives a detailed description of the organizational process, through which "being the person with body dysfunctions" is slowly and routinely constructed.

Keywords: disability, sport, social construction of meanings, grounded theory 


\section{Wprowadzenie}

Od przeszło pół wieku w literaturze socjologicznej podejmowane są zagadnienia dotyczące społeczeństwa jako bytu "skonstruowanego", a liczni badacze potwierdzili klasycznymi już dziś pracami, że otaczająca nas rzeczywistość ma wymiar procesualny i stanowi wytwór współdziałających ze sobą jednostek [Gobo 2008]. Z tego względu praca socjologów miała często na celu dekonstrukcję lub rekonstrukcję mechanizmów stojących za wybranymi fenomenami życia społecznego, w tym także niepełnosprawnością. I tak na przykład, w swoich badaniach na temat głuchoty, H. Lane [1997, s. 154] pokazuje, że w kształtowaniu losu ludzi głuchych dominujące i współzawodniczące ze sobą szczególnie są dwie wizje głuchoty. Jedna konstruuje niesłyszącego w kategoriach inwalidztwa, druga pokazuje go jako członka mniejszości językowej. W podobny sposób odkryto społeczną i polityczną podstawę bardzo wielu zróżnicowanych kwestii społecznych, począwszy od seksualności do ułomności, od rasy do choroby, od dewiacji do wydajności pracy akademickiej [(Gobo 2008].

W niniejszym artykule również postaram się pokazać, jak rzeczywistość społeczna jest konstruowana przez jej aktywnych aktorów, przy czym skoncentruję się na czterech kluczowych obszarach.

Po pierwsze, celem badań jest pokazanie rekonstrukcji pojęcia niepełnosprawności przez bezpośrednią obserwację interakcji badanych osób. Chodzi tutaj przede wszystkim o redefiniowanie pojęcia niepełnosprawności (i sposobu postrzegania oraz traktowania ludzi nią dotkniętych) przez osoby pełnosprawne pod wpływem doświadczeń związanych z obserwacją działań osób z dysfunkcjami ciała, uprawiających sport. Po drugie, niniejsze badanie koncentruje się na relacjach osób niepełnosprawnych uprawiających sport ze swoimi pełnosprawnymi kolegami. Po trzecie, artykuł bierze także pod uwagę rolę jaką odgrywa przestrzeń, przedmioty $\mathrm{i}$ ich usytuowane $\mathrm{w}$ organizacyjnym konstruowaniu pojęcia niepełnosprawności. Po czwarte, $\mathrm{w}$ studiach nad niepełnosprawnością często brakuje propozycji praktycznych, możliwych do zastosowania $\mathrm{w}$ działaniu, w związku z tym w moich badaniach podejmuję również starania, aby ich wyniki miały charakter aplikacyjny.

Innymi słowy $\mathrm{w}$ przeprowadzonych badaniach interesował mnie proces przemian $\mathrm{w}$ sposobie percypowania niepełnosprawnego sportowca przez osoby pełnosprawne współuczestniczące w podstawowym działaniu jakim było uprawianie sportu. Była to obserwacja osoby niepełnosprawnej, która ze względu na uwarunkowania instytucjonalne mogła trenować na obiektach pełnosprawnych sportowców, w tym samym czasie co oni, ale także wspólnie wykonywać z nimi niektóre czynności. W ten sposób osoby pełnosprawne były nie tylko bezpośred- 
nimi obserwatorami działań niepełnosprawnego, ale też mogły podejmować je wspólnie z nim, stając się tym samym współuczestnikami osoby niepełnosprawnej $\mathrm{w}$ procesie trenowania.

\section{Problematyka niepełnosprawności na tle literatury przedmiotu}

Sport osób niepełnosprawnych został zapoczątkowany w ubiegłym stuleciu, a na jego rozwój szczególny wpływ miały nowo powstające organizacje, których celem było kierowanie i zarządzanie różnymi formami aktywizowania ludzi dysfunkcjami psychofizycznymi [Rekowski, Wilk 1997, s. 109-112]. Na przestrzeni lat zmianom ulegały zarówno warunki, jak i możliwości uprawniania sportu przez osoby niepełnosprawne, a kolejne towarzyszące temu procesowi wydarzenia wyznaczały stopniowe przechodzenie od rehabilitacji przez rekreację do sportu wyczynowego [Molik, Morgulec-Adamowicz, Kosmol 2008, s. 63]. Początkowo sport niepełnosprawnych służył przede wszystkim usprawnianiu funkcjonalnemu osób ze schorzeniami narządu ruchu. Później rozwinął się sport wyczynowy, a w jego obszarze sport paraolimpijski.

Dynamiczny rozwój sportu osób niepełnosprawnych rozpoczął się w drugiej połowie XX wieku. Między innymi przyczyniła się do tego zmiana w podejściu do rozwiązywania problemów osób niepełnosprawnych. W tym okresie w nauce dokonała się bowiem zmiana podejścia teoretycznego w odniesieniu do samej niepełnosprawności, od funkcjonalnej teorii zdrowia i choroby, analizującej niepełnosprawność przede wszystkim z perspektywy teorii ról, po teorie interakcjonistyczne, uwzględniające perspektywę osób niepełnosprawnych, czyniąc z nich podmioty działania w ramach różnorodnych form stosunków społecznych. Funkcjonaliści wyodrębniali zespół ról pełnionych przez osoby niepełnosprawne w społeczeństwie, analizowali problemy synchronizowania tych ról i konflikty między nimi oraz problemy adaptacji społecznej. „Rola niepełnosprawnego” wyodrębniona $w$ ramach tego podejścia teoretycznego polega na zaakceptowaniu przez przedstawicieli tej grupy, swej zależności od innych w zamian za uprawomocnienie ich statusu. Interakcjoniści uważają natomiast, że choroba (a także niepełnosprawność) jako zjawisko społeczne pojawia się na skutek oddziaływania czynników zewnętrznych (środowiskowych). W związku z tym wyróżniają dwa poziomy analizy: stosunków interpersonalnych, w trakcie których mają miejsce zmiany w zachowaniach ludzi, oraz poziom instytucji społecznych, które mają za zadanie skategoryzowanie i ocenę indywidualnych zachowań [Uramowska-Żyto 2010]. W tym rozumieniu osoby niepełnosprawne są ludźmi z piętnem, którym jest kalectwo, ułomność, choroba, co dyskredytuje ich w oczach 
innych. W związku z tym za przydatne i adekwatne do rozpatrywania sytuacji osób niepełnosprawnych uznano koncepcje niepełnosprawności w języku teorii dewiacji społecznej i naznaczania społecznego. Wykorzystano w nich kierunek wyznaczony przez E. Goffmana [1963, 1961, 1959], H. Beckera [1963, 1953] i E. Lemerta [1951]. Z tego względu, definiując pojęcie niepełnosprawności należy wziąć pod uwagę podstawowe rozróżnienia terminologiczne związane z ewolucją i zmianami w sposobie postrzegania osób niepełnosprawnych. Zanim przyjęło się pojęcie osoby niepełnosprawnej, w powszechnym użyciu było określenie „inwalida” i „inwalidztwo”, które etymologicznie wiązało się z łacińskim invalidus i oznaczało człowieka bezsilnego, słabego, schorowanego. Termin inwalida używany był zamiennie z określeniami, takimi jak: „osoba z odchyleniami od normy”, "Osoba trwale poszkodowana na zdrowiu", osoba upośledzona". Z czasem jednak zrezygnowano $\mathrm{z}$ tego terminu ze względu na jego jednoznacznie negatywne konotacje [Balcerzak-Paradowska 2002]. Ewolucja ta polega na odchodzeniu od przekonania, że osoba niepełnosprawna nie potrafi zapewnić sobie samodzielnie odpowiedniej jakości życia. Wizerunek osoby niepełnosprawnej, jako niesamodzielnej, bezbronnej, niepotrafiącej samodzielnie zadbać o siebie i własne interesy, jednym słowem wizerunek osoby „innej” od reszty „normalnego” społeczeństwa, zastępowany był coraz częściej przez wizerunek osoby, która nieustannie napotyka na bariery tworzone przez to "normalne” społeczeństwo. Właśnie te bariery, a nie cechy osoby niepełnosprawnej, stanowią główną przeszkodę w funkcjonowaniu na równych prawach w społeczeństwie [Balcerzak-Paradowska 2002].

Niepełnosprawność fizyczna może być zatem definiowana na wiele sposobów. Jednym z nich jest jej rozumienie jako trwałe, morfologiczne lub funkcjonalne uszkodzenie aparatu ruchu (kośćca, mięśni, stawów, mechanizmów sterowania ruchem), które ze względu na swoją specyfikę i wielkość w różnym stopniu utrudnia lub uniemożliwia wykorzystanie tego aparatu w podejmowaniu aktywności życiowej [Tasiemski, Koper 2013, s. 111]. Ten rodzaj niepełnosprawności jest reprezentowany przez dużą grupę różnorodnych urazów i schorzeń. Zalicza się do nich między innymi: amputacje i wrodzone ubytki kończyn, porażenia i niedowłady kończyn powstałe w wyniku urazów lub chorób rdzenia kręgowego, różne postacie mózgowego porażenia dziecięcego, choroby mięśni i choroby stawów [Sobiecka 2013]. Należy podkreślić, że nabycie trwałej dysfunkcji narządu ruchu wiąże się z szeregiem poważnych konsekwencji zarówno tych bezpośrednio związanych z zaburzeniem określonych funkcji ruchowych, jak i tych dotyczących psychicznego i społecznego funkcjonowania osoby w jej środowisku życiowym [Tasiemski, Koper 2013, s. 112].

Zgodnie z definicją przyjętą przez Międzynarodową Organizację Zdrowia (WHO) niepełnosprawność jest definiowana jako wszelkie ograniczenie lub braki wynikające z uszkodzenia zdolności wykonywania czynności w sposób i w zakre- 
sie uważanym za normalny dla człowieka. Przedstawiona definicja odnosi się do niepełnosprawności funkcjonalnej jednostki i jest odróżniana od niepełnosprawności społecznej (handicap), która oznacza mniej uprzywilejowaną lub mniej korzystną sytuację danej osoby, wynikającą z uszkodzenia i niepełnosprawności funkcjonalnej, która ogranicza lub uniemożliwia jej wypełnianie ról związanych z jej wiekiem, płcią oraz sytuacją społeczną i kulturową [WHO 1980, s. 29]. Oprócz wymienionych dwóch definicji WHO podaje trzecią, zgodnie z którą niepełnosprawność, zwana tutaj uszkodzeniem, oznacza wszelki brak lub anormalność anatomiczną struktury narządów oraz brak lub zaburzenie funkcji psychicznych czy fizjologicznych organizmu [Barnes, Mercer 2008, s. 22].

Problematyka niepełnosprawności zarówno $\mathrm{w}$ dyskursie naukowym, jak i społecznej percepcji to zagadnienie, które w dalszym ciągu jest szeroko dyskutowane i poddawane wszechstronnej analizie. W efekcie doprowadziło to do ukształtowania się różnych perspektyw oraz sposobów ujmowania tego zagadnienia [Barnes, Mercer 2004, s. 18]. Do szczególnie interesujących, ze względu na swój przeciwstawny charakter, należą dwa z nich. Są to model społeczny i indywidualny niepełnosprawności [Finkelstein 1993]. Ten ostatni oparty był na założeniu, że niepełnosprawność jest osobistą tragedią jednostki. W modelu tym problem niepełnosprawności jest "umiejscowiony” w samej jednostce, a jego przyczyny dostrzega się $\mathrm{w}$ funkcjonalnych ograniczeniach lub psychologicznych ubytkach, będących skutkami niepełnosprawności [Oliver 1983]. Z kolei w ramach społecznego modelu niepełnosprawności funkcjonuje pogląd, że niepełnosprawność w znacznej mierze wynika z przeszkód i barier doświadczanych przez osoby nią dotknięte, a będących wynikiem "upośledzającego" społeczeństwa [Finkelstein 1980; Oliver 1983; Abberley 1987]. Zatem nie indywidualne ograniczenia, ale niedostarczenie przez społeczeństwo odpowiednich usług oraz niezaspokajanie potrzeb osób niepełnosprawnych "tworzą" niepełnosprawność. $\mathrm{W}$ modelu tym przyczyn niepełnosprawności nie szuka się $\mathrm{w}$ jednostce, lecz w środowisku oraz różnego rodzaju barierach społecznych, ekonomicznych i fizycznych [Barnes i in. 1999; Oliver 1990; Swain i in. 1993].

W związku z tym niepełnosprawność jest zjawiskiem biologicznym, psychofizycznym oraz medycznym, ale jest ona także konceptualnym produktem wytworzonym w codziennych interakcjach pomiędzy aktorami społecznymi, sprawia to, że można ją także określić mianem „zjawiska społecznego". Jest to zgodne z poglądem, według którego charakterystyki przypisywane jednostkom posiadającym fizyczne ułomności są kulturowo zdeterminowane. Innymi słowy, to co niepełnosprawni mogą robić, a czego nie zależy zarówno od ich wewnętrznych cech, jak i zewnętrznych uwarunkowań społecznych. Problemem zatem jest tutaj nie zaprzeczanie różnicom $\mathrm{w}$ poznawczych zdolnościach osób niepełnosprawnych, ale raczej odwrócenie perspektywy. Wiemy bowiem z prac psycholożki 
poznawczej E. Rosch [1973, 1978], że kategoria poznawcza jest strukturą w ciągłej przemianie. Ponadto nauczyliśmy się od H. Sacksa [1972] koncepcji „narzędzi kategoryzacji uczestnictwa" (membership categorization devices), która mówi o niestabilności wzajemnych i kulturowych zależności pomiędzy kategoriami.

W związku z tym niniejszy artykuł będzie prezentował rozważania oparte na danych dotyczących przypadku osoby uprawiającej sport, której niepełnosprawność została określona wspólnie na podstawie definicji sytuacji z członkami środowiska skupionego wokół jednego działania, jakim jest uprawianie sportu, czyli w przeważającej większości na podstawie subiektywnej oceny badanych osób i ich najbliższego otoczenia.

\section{Teoretyczne podejście i metodologiczne podstawy badań}

Badanie stanowiące podstawę niniejszego artykułu ${ }^{1}$ zostało przeprowadzone dzięki połączeniu trzech różnych, ale komplementarnych podejść - etnometodologii, etnografii i metodologii teorii ugruntowanej. Pierwsze podejście ma charakter fenomenologicznej orientacji i było niezwykle użyteczne $\mathrm{w}$ rozpatrywaniu niepełnosprawności jako procesu i konstruktu organizacyjnego, a także jako dziejącego się ciągle zjawiska. Etnometodologia proponuje zatem logikę odkrywania i dystansu, mając na celu rozpatrywanie niepełnej sprawności jednostki w nowym świetle. Etnografia natomiast była metodologią najlepiej dopasowaną do zbierania danych, ponieważ umożliwia ona zbieranie bogatych w szczegóły informacji, które są niezapośredniczone przez interpretacje uczestników [Gilbert, Mulkay 1983; Heritage 1984, s. 236]. Metodologia teorii ugruntowanej (w wersji Straussa i Corbin 1990) dostarczyła natomiast rygoru proceduralnego w zbieraniu i analizowaniu danych.

Prezentowane studium przedstawia badanie etnograficzne przeprowadzone $\mathrm{w}$ jednej z organizacji sportowych, w której wspólnie z osobami pełnosprawnymi ćwiczyła osoba niepełnosprawna. W badanej grupie znalazły się osoby reprezentujące różne rodzaje niepełnosprawności ruchowej. Były wśród nich osoby z porażeniem cztero- i dwukończynowym, porażeniem mózgu, a także po amputacjach kończyn dolnych. W grupie osób badanych (członków organizacji sportowej) znalazło się w sumie 10 kobiet 16 mężczyzn w wieku od 18 do 53 lat.

Przedmiotem badań były organizacyjne praktyki, zasoby i bariery z bezpośredniego otoczenia obecne we wspomnianej organizacji (klubie sportowym), które razem konstruowały szczególne znaczenie niepełnosprawności, a w szcze-

1 Artykuł powstał na podstawie badań przeprowadzonych w ramach projektu finansowanego przez Narodowe Centrum Nauki, SONATA 9 (nr projektu 2015/17/D/HS6/00184). 
gólności tożsamość sportowca z niepełną sprawnością. Początkową intencją badacza było zbadanie zjawiska integracji osoby niepełnosprawnej z resztą członków klubu sportowego. Jednak w miarę jak badanie się rozwijało jego cel uległ zmianie. Udało się bowiem zauważyć, że niepełnosprawność jest „zjawiskiem społecznym", poza tym, że jest zjawiskiem biologicznym, psychofizycznym oraz medycznym. Jest ona konceptualnym produktem wytworzonym w codziennych interakcjach pomiędzy osobą niepełnosprawną i pełnosprawnymi współuczestnikami badanego środowiska. Przykładowo, pełnosprawni członkowie klubu sportowego posiadali początkowo społeczną reprezentację osoby niepełnosprawnej, bazującą na schematach poznawczych, które zostały przez nich zinternalizowane w procesie socjalizacji. Innymi słowy, miały one pewną określoną wizję tego jaka jest osoba z niepełną sprawnością, co może ona zrobić a czego nie i czego w związku z tym należy po niej oczekiwać. Wizja ta odwoływała się do społecznych stereotypów i uprzedzeń, zgodnie z którymi osoba pełnosprawna postrzega ludzi z różnego rodzaju dysfunkcjami ciała jako niesamodzielnych, zależnych od innych i niepotrafiących poradzić sobie ze sprawami życia codziennego. Tymczasem osoba, która uprawia sport, zaprzecza temu stereotypowi i w ten sposób przełamuje negatywny wizerunek całej kategorii ludzi niepełnosprawnych. Sama zaś jako współuczestnik określonych działań staje się bezpośrednim motorem zmian dokonujących się wśród członków danej społeczności tworzącej środowisko koncentrujące się wokół instytucji sportowej. Jednocześnie osoby pełnosprawne, które tworzą owo środowisko, stwarzają nową koncepcję niepełnosprawności na podstawie praktyk organizacyjnych i codziennych rytuałów odbywających się wewnątrz, ale także w otoczeniu ukonstytuowanego na podstawie wspólnych zainteresowań środowiska sportowego. Organizacyjne i dyskursywne praktyki, które zachodziły w ramach tego środowiska, zdecydowanie przyczyniły się do rekonstrukcji tożsamości osoby niepełnosprawnego sportowca.

W związku z tym, aby móc zrozumieć specyfikę badanych procesów, ramą teoretyczną uczyniłem symboliczny interakcjonizm, gdzie świat społeczny jest konstruktem, a język jego największym i najważniejszym narzędziem [Blumer 1969]. Zgodnie z przywołanymi założeniami teoretycznymi, to w jaki sposób będziemy patrzeć na rzeczywistość i na nas samych, jest odzwierciedleniem otaczającego nas świata społecznego. Jednocześnie świata społecznego nie można rozumieć w kategoriach prostych, przyczynowych związków czy analizować przez stosowanie wobec zdarzeń społecznych praw uniwersalnych [Charmaz 1994]. Wynika to $\mathrm{z}$ faktu, że ludzkie działania są oparte na społecznych znaczeniach, takich jak: intencje, motywy, przekonania, zasady i wartości [Hammersley, Atkinson 2007]. Na gruncie symbolicznego interakcjonizmu podkreśla się wagę procesów interpretowania obiektów i zjawisk, definiowania siebie i sytuacji w sposób właściwy dla danej roli [Becker 1953, 1963]. Zgodnie z tym ujęciem natura 
jednostki jest twórcza, rzeczywistość zaś jako intersubiektywny wytwór uczestników jest dynamiczna i zmienna. $Z$ tego względu nie da się odkryć "praw” rządzących ludzkim zachowaniem bez uwzględnienia symbolicznego charakteru postrzegania świata przez jednostki i symbolicznego charakteru interakcji zachodzących pomiędzy aktorami społecznymi [Blumer 1969].

Rekonstruowanie procesów, interakcji, interpretacji i działań posiadających sens dla tworzących je jednostek wymaga poznania punktu widzenia aktora, uchwycenia wszystkiego co posiada dla niego znaczenie i analizowania każdego zjawiska w kontekście tych znaczeń [Blumer 1966]. W związku z tym, biorąc pod uwagę powyższe odniesienia teoretyczne $\mathrm{w}$ badaniach stanowiących fundament niniejszego artykułu, odwołuję się do subiektywnej perspektywy badanych, czyniąc ich własny punkt widzenia podstawą do konstruowania uogólnień teoretycznych.

Podejmuję próbę uchwycenia zarówno refleksyjnego charakteru działających ludzi w procesie indywidualnego rozwoju, jak i wymiaru grupowych, ponadjednostkowych relacji i oddziaływań, a wszystko to przy uwzględnieniu procesualności i zarazem sytuacyjnego ugruntowania każdej symbolicznej interakcji [Denzin 1972]. To właśnie spełnienie takich wymogów powoduje, że metodologia musi zostać dobrana według kryterium jej funkcjonalności i potencjału dla zastosowania przy określonych założeniach ontologicznych i epistemologicznych badacza. W związku z tym, aby przeprowadzić tak zaprojektowane badanie, użyłem teoretycznych i metodologicznych narzędzi metodologii teorii ugruntowanej [Glaser, Strauss 1967; Glaser 1978; Konecki 2000]. Moim zamiarem było zaobserwowanie organizacyjnych praktyk instytucji sportowej (klubu), które przekształcały osobę niepełnosprawną $\mathrm{w}$ sportowca $\mathrm{z}$ niepełnosprawnością. W związku z tym do badania wykorzystałem wywiady przeprowadzone z osobami pełnosprawnymi uprawiającymi sport wspólnie $z$ osobą niepełnosprawną [Glaser, Strauss 1967, s. 45-53; Charmaz 2006, s. 74], a także obserwacje przeprowadzone w środowisku sportowym (klubie).

\section{Wyniki badań}

Przeprowadzone badania pozwoliły na określenie mechanizmów oraz etapów składających się na proces włączania do grupy osoby niepełnosprawnej oraz jej konsolidacji ze środowiskiem osób pełnosprawnych uprawiających sport. Zjawisko to było bezpośrednio związane z procesem rekonstruowania pojęcia samej niepełnosprawności, które okazało się być niezwykle płynne i elastyczne, podlegając grupowym negocjacjom i ustaleniom na podstawie wewnątrzorganizacyjnych uwarunkowań. 
Początkowo członkowie klubu sportowego (osoby pełnosprawne) nie posiadali żadnej precyzyjnej reprezentacji osoby niepełnosprawnej. Innymi słowy, nie wiedzieli kim dokładnie taka osoba jest, oprócz wdrukowanego stereotypowego jej postrzegania. Pewne, dość mgliste i zazwyczaj posiadające niewiele wspólnego z rzeczywistością, przeświadczenia jakie mieli w tym zakresie członkowie wspomnianego środowiska, opierały się zazwyczaj na niezweryfikowanych przez nich schematach poznawczych, które stanowiły w istocie wytwór nierzadko obecnej w społeczeństwie ignorancji w zakresie znajomości zagadnień związanych z problematyką niepełnosprawności. W związku z tym już sama sytuacja pojawienia się $w$ ich bezpośrednim otoczeniu osoby niepełnosprawnej stanowiła nierzadko duże wyzwanie zarówno interakcyjne, jak i interpretacyjne, dotyczące zestawienia bieżących doświadczeń z dotychczasową wiedzą, które to okazywały się być niespójne, a w konsekwencji prowadziły do pojawienia się dysonansu poznawczego. Towarzyszyło temu zaskoczenie, pogłębiające się w miarę, gdy osoba niepełnosprawna zaczynała wchodzić w rolę sportowca, a więc kogoś kojarzonego z ponadprzeciętnymi zdolnościami fizycznymi, co dla wielu spośród reprezentantów badanej grupy było dotychczas zarezerwowane wyłącznie dla ludzi pełnosprawnych. Pogłębiający się $\mathrm{w}$ związku $\mathrm{z}$ tym dysonans poznawczy rodził z kolei poczucie niezrozumienia, czasem nawet lęku wynikającego z pojawienia się konieczności zestawienia ze sobą dwóch przeciwstawnych i w percepcji badanych osób, wykluczających się zjawisk: dysfunkcjonalności organizmu oraz fizycznej sprawności.

Przyznam się, że początkowo to było dla mnie dziwne, takie nawet trochę nierealne, że ktoś niepetnosprawny może być w naszym środowisku, tak zupetnie bezpośrednio, bo jakoś wydało mi się, że nasz światy się po prostu nie przenikają. Jasne, styszało się o takich czy innych niepetnosprawnych sportowcach, ale to raczej tak w mediach, a nie w życiu, bo nigdy wcześniej nie spotkałem takiej osoby (...) może tė̇ się tym po prostu wcześniej nie interesowałem (w. 13.7)

Pełnosprawni członkowie klubu musieli zatem nie tylko podjąć pracę nad kontaktem z nowoprzybyłym niepełnosprawnym, ale także stanęli przed koniecznością zrozumienia, a wcześniej wypracowania znaczenia samej niepełnosprawności, jak również poznania innych pojęć z nią związanych. Przy czym nie były to wyłącznie powierzchowne rekonstrukcje, ale przeważnie dotyczyły one przemian $\mathrm{w}$ sposobie postrzegania rzeczywistości instytucjonalnej oraz dotychczas żywionych przekonań i poglądów na temat niepełnosprawności. Była to więc rekonstrukcja na poziomie percepcji, która dokonywała się przez zaburzenie dotychczasowego, ugruntowanego światopoglądu, konstruowanego w zwykły sytuacjach życia codziennego.

Uzgadnianie sensu znaczeń określonych pojęć odbywało się w trakcie wykonywania codziennych czynności i stanowiło istotny element socjalizacji. Pojawie- 
nie się osoby niepełnosprawnej wymusiło dokonanie swego rodzaju korygowania znaczenia pojęć, a więc sposobu w jaki dana osoba postrzegała dotychczas istotę bieżącej sytuacji. Stereotypowe wyobrażenia powoli ustępowały wiedzy budowanej $\mathrm{w}$ bezpośrednim doświadczeniu w interakcjach z osobą niepełnosprawną. $\mathrm{W}$ ten sposób dochodziło do przełamywania utartych schematów, które same w sobie składały się z kilku kluczowych (sub)procesów (o których nieco później), pozwalających wyjaśnić przemiany dokonujące się w zakresie zarówno nabywania członkostwa w grupie, jak i towarzyszącemu temu procesowi redefiniowania pojęcia niepełnosprawności. Jednocześnie formułując swoją koncepcję niepełnosprawności czynili to przez organizacyjne praktyki i rytuały odgrywane w odniesieniu do osoby niepełnosprawnej. Dotyczyły one przede wszystkim różnych czynności podejmowanych $\mathrm{w}$ związku z grą $\mathrm{w}$ towarzystwie osoby niepełnosprawnej, w tym wspólne uczestnictwo w treningach, ale także współdzielenie w ramach różnych obszarów przestrzeni należących do klubu, takich jak: sala gimnastyczna, siłowania czy bardziej intymnych, a więc szatnia czy prysznic. Zwłaszcza dwa ostatnie z wymienionych miejsc stanowiły spore wyzwanie dla pełnosprawnych członków klubu, bowiem wymagały od nich przedsiębrania odpowiednich technik interakcyjnych w stosunku do osoby niepełnosprawnej, jak i do siebie nawzajem. Bardzo obrazowo oddają to słowa jednego z moich rozmówców:

No nie było łatwo, zwłaszcza tak, gdy trzeba było jakoś tak zagadać, bo nie bardzo wiedzieliśmy jako to zrobić, ale największy problem to mieliśmy, to znaczy ja miatem, ale wiem, że inni chłopaki, też nie mieli z tym prosto, żeby jakoś się odpowiednio zachować no na przykład w sytuacji w której być może Arek (imię zmienione - przyp. autora), potrzebowatby jakieś pomocy, albo co. No pamiętam, jak było dziwnie w szatni, no to było chyba najtrudniejsze, no, bo nie wiesz jak się zachować, tak, żeby też nie wyszło jakoś idiotycznie, a jednocześnie jesteś trochę ciekawy, jak taka osoba wyglada, jak sobie radzi no i w ogóle tak jakoś dziwnie było wtedy (w. 13.9)

Istotnym warunkiem mającym wpływ na przemiany w percepcji członków klubu były nie tylko określone okoliczności, ale także czas spędzony w obecności osoby niepełnosprawnej oraz wiedza kumulowana wraz z kolejnymi doświadczeniami płynącymi z takich interakcji. Biorąc zaś pod uwagę częstotliwość oraz długotrwałość kontaktów pełnosprawnych członków klubu z osobą niepełnosprawną, można zauważyć, że w miarę upływu czasu oraz intensyfikacji relacji interpersonalnych pomiędzy wymienionymi aktorami społecznymi mamy do czynienia ze stopniowym neutralizowaniem, wcześniejszych obaw oraz poczucia niepewności co do kontaktów z osobą niepełnosprawną, a w skrajnych przypadkach nawet żywionych wobec niej uprzedzeń. Początkowo miały one formę goffmanowskiego "taktownego niezauważania" [Goffman 2006] i oznaczały swoistą fazę przejściową (liminalną), w której pełnosprawni przedstawiciele klubu stopniowo oswajali się z niepełnosprawnością jednego ze swoich członków, która to 
cecha nadal jednak stanowiła dla nich tę własność jednostki, przez pryzmat której była on oceniana i definiowana. Oznaczało to, że dysfunkcja fizyczna osoby niepełnosprawnej nie stanowiła już dla większości członków klubu wyzwania interpretacyjnego, jednak nadal dominowała przy jej opisie, będąc $w$ istocie podstawą nadawanej jednostce tożsamości. Innymi słowy niepełnosprawność przestawała być tabu czy też swoistą enigmą i czymś co dyskredytowało [Goffman 2006] daną osobę, czyniąc z niej w świadomości wielu pełnosprawnych sportowców, człowieka niezdolnego do aktywności fizycznej. Przeciwnie, w oczach przedstawicieli klubu, osoba taka zdobywała pełną legitymację do tego by cieszyć się statusem sportowca, jednak $w$ dalszym ciągu postrzeganego przez pryzmat posiadanej przez nią niepełnosprawności.

Wiesz, to nie przyszło tak od razu, ale po pewnym czasie jakoś tak się już oswoiliśmy z widokiem Arka, że nie dziwit nas, nie wzbudzał naszej ciekawości. Po prostu wpisat się tak jakoś w ten nasz codzienny krajobraz. I jako osoba niepetnosprawna, był częścią naszego życia, choćz drugiej strony trudno było tak zupetnie zapomnieć, że to osoba niepetnosprawna (w. 13.14)

W ten sposób kończył się pewien etap w kształtowaniu stosunków pomiędzy osobą niepełnosprawną a jej pełnosprawnymi kolegami, który polegał z jednej strony na wypracowaniu swoistego modelu interakcyjnego, opartego na powolnym konstytuowaniu się relacji istniejących pomiędzy wspomnianymi powyżej aktorami społecznymi jako równorzędnych podmiotów w ramach klubu sportowego, z drugiej zaś na operowaniu pojęciem niepełnosprawności pozbawionym pejoratywnych konotacji.

W procesie tym ważną rolę odgrywali organizacyjni przewodnicy, a najważniejszym z nich był trener, który, wykorzystując swoją uprzywilejowaną pozycję $\mathrm{w}$ strukturze organizacyjnej klubu, wpływał na kształtowanie się relacji interpersonalnych pomiędzy wszystkimi jego członkami, ale też pełnił rolę osoby objaśniającej to co poszczególne wydarzenia za sobą pociągały, a także podającej ich interpretację. Jak podkreśla H. Lane [1997, s. 155-156] każdy profesjonalista (np. lekarz, terapeuta) ma swoją wizję danego zjawiska, która wpływa na jego konstrukcję. Podobnie trener starał się swoim działaniem oraz przykładem pokazać jak należy postępować względem osoby niepełnosprawnej. Warto przy tym podkreślić, że do opisania relacji łączących osobę niepełnosprawną uprawiającą sport a tą, która stanowi dla niej swoisty drogowskaz ukierunkowujący ją na pożądane działanie, można zastosować pojęcie trenowania (coaching) wprowadzone przez A. Strasussa [1996, s. 94]. Taka relacja zachodzi przeważnie pomiędzy osobami, które charakteryzują się określonymi cechami, ważnymi z punktu widzenia danej sytuacji. Główne cechy relacji trenowania wypływają z tego, że uczeń przechodząc kolejne etapy potrzebuje przewodnictwa. Nie chodzi tu tylko o konwencjonalny sens nauczania umiejętności, ale również o to, że w czasie poruszania 
się przez "trenowanego" w przestrzeni społecznej zachodzą istotne procesy, wymagające stosowanego wytłumaczenia, w czym kluczową rolę odgrywa "trener". Kwestie te opisują również Bourdieu i Wacquant [2001, s. 220], podkreślając, że „nauczanie zawodu, rzemiosła, fachu, (...) wymaga pedagogii trochę innej niż ta, która przystoi nauczaniu wiedzy (...). Wiele sposobów myślenia i działania, i to często tych najbardziej żywotnych, jest przekazywanych w formie praktycznej, wprzekazie całościowym i dzięki praktykom opartym na bezpośrednim kontakcie między nauczającym i uczącym się". Przy czym wspomniani autorzy nacisk kładą na charakterystykę procesu „nauczania”, Strauss natomiast odnosi się w tym kontekście do przemian tożsamościowych, jakie stają się udziałem samego „ucznia". Dobrze oddaje to poniższy fragment wypowiedzi jednego z moich rozmówców:

Aleks byt naszym trenerem jak pamiętam. Chyba od zawsze tak byto, z tego, co slyszatem od innych. I kiedy ja przyszedtem to on tak się mna zainteresowat, pokazat jak i co trzeba, jakie są zasady $i$ w ogóle tak się no interesował właśnie. Tak się czułem pewniej jak on byt i jak mówit, co trzeba robić. Inni z resztą też go stuchali, bo on ma duża wiedzę, on grał kiedyśs naprawdę profesjonalnie (w. 13.4)

Trener jest także tą osobą, która dba, a zarazem pokazuje własnym przykładem, jak należy traktować i w jaki sposób odnosić się do niepełnosprawnego sportowca. Rodzaj języka oraz sam charakter relacji łączących trenera z osobą niepełnosprawną bardzo silnie rzutują na postrzeganie tej ostatniej przez pozostałych członków klubu. Do pewnego stopnia naśladując zachowania trenera inne osoby, zaczynają mniej lub bardziej świadomie przyjmować określoną definicję sytuacji wraz z towarzyszącym jej językiem. W ten sposób dochodzi do stopniowej akceptacji osoby niepełnosprawnej i jej obecności w danym środowisku, czego bezpośrednim objawem jest tak zwana "naturalizacja” wspólnej gry i treningu, oznacza to przejście z koncentrowania uwagi na osobie niepełnosprawnej i jej dysfunkcji, na wykonywanych przez nią czynnościach sportowych. Jest to więc zaprzestanie negatywnego wyróżniania osoby niepełnosprawnej spośród innych zawodników, które oznacza, że od tej pory jest ona postrzegana przez pryzmat swoich zdolności, umiejętności i doświadczenia, a nie dysfunkcyjnego ciała. Bezpośrednim i namacalnym tego objawem jest równe traktowanie, a więc stawianie takich samych wymagań przed osobą pełno i niepełnosprawną, a także nie oszczędzanie jej ze względu na posiadaną dysfunkcję.

Nie byto to takie oczywiste, żeby tak po prostu traktować Bartka, bo on jako osoba niepetnosprawna, to wydawało się mi i nam wszystkim chyba, że jest, jakby to powiedzieć, inny wo tym znaczeniu, że wymaga czegoś innego i, że trzeba go traktować tak bardziej pobtażliwie, więcej mu darować, dawać takie fory, bo tak to ja widziatem. Ale potem okazało się, że to nie o to chodzi i jak się lepiej poznaliśmy, to stało się jasne, że on (Arek - przyp. autora) jest taki jak my, kiedy gra 
i trzeba go traktować tak samo, bo to właśnie jest w porządku, a nie kiedy jest na pozycji uprzywilejowanej, bo on sam tego nie chce i nie lubi (w. 13.5)

$\mathrm{W}$ proces ten wkomponowane jest redefiniowanie znaczeń i nowa operacjonalizacja starych pojęć. Doświadczenia nabywane w klubie zmieniają sposób postrzegania niepełnosprawności i osoby nią dotkniętej. Równolegle z redefiniowaniem pojęcia niepełnosprawności, w świadomości osób tworzących owo środowisko, następuje proces rekonstruowania pojęcia pełnosprawności. Ta ostatnia kategoria staje się zresztą kryterium odróżniającym „nienormalność” (czy inaczej rzecz ujmując nie normatywności), od tego co za „normalność” się uważa. $Z$ upływem czasu i kumulowaniem przez poszczególne osoby doświadczeń, obie kategorie w coraz większym stopniu brane są $\mathrm{w}$ nawias, oznacza to, że zaciera się w pewnym przynajmniej zakresie granica pomiędzy tym co „normalne” $i$ "nienormalne". Oba pojęcia nie są więc dychotomicznie istniejącym tandemem, o stałym i skonkretyzowanym zakresem znaczeniowym, a funkcjonują raczej jako pojęcia uczulające, o sytuacyjnym i zmiennym znaczeniu.

No normalna osobę to się niby zna, to znaczy, wiesz jak to osoba, a z niepetnosprawnościa to już jest gorzej, bo masz różne jej rodzaje, stopnie (...) ale też każdy przypadek jest zawsze trochę inny (...) W sumie przez ten czas jak tu jestem to inaczej patrze na te spraw (...) a to kim jest osoba sprawna i niepetnosprawna to nie jest teraz dla mnie takie oczywiste (...) (w. 12.3)

Wyniesiony i pochodzący spoza klubu sportowego obraz normy społecznej zostaje skonceptualizowny w nowy, odmienny sposób. Początkowe odwzorowanie pewnej społecznej kalki zostaje stopniowo zastępowane przez rekonstruowane na nowo pojęcie normy i normalności wytwarzane w ramach środowiska sportowego. Niepełnosprawność nabiera innego charakteru, zostaje na nowo zrekonstruowana na bazie aktualnego doświadczenia.

Jednocześnie warto podkreślić, że przeciętna osoba pełnosprawna wchodząca w skład klubu posiadała początkowo w miarę jednolity, choć zazwyczaj uproszczony i bazujący na stereotypach, obraz osoby niepełnosprawnej. Dopiero z upływem czasu spędzonego z osobą niepełnosprawną pojęcie niepełnej sprawności rozmywa się i staje niejednolite definicyjnie. I choć może wydawać się to zaskakujące, to właśnie rosnąca wiedza i doświadczenie, a w związku z tym przyswajanie określonych wzorców interpretacyjnych sprawiało, że pojęcie niepełnosprawności przechodziło transformację z poziomu stereotypowej konkretyzacji do poziomu uczulającego uogólnienia. W wyniku dokonanych rekonstrukcji pojęcia niepełnosprawności członkowie klubu posługiwali nie tyle jedną skonkretyzowaną definicją, lecz różnymi jej wariantami, będącymi w istocie pochodną charakteru i rodzaju relacji z osobą niepełnosprawną. Innymi słowy, czynnikami interweniującymi $\mathrm{w}$ tym procesie były intensywność oraz częstotliwość kontaktów z daną osobą, a także wcześniejszymi doświadczeniami z udziałem innych niepełnosprawnych. 
Ostatecznie więc przejawem dokonujących się przemian na poziomie percepcji, widocznym w bezpośrednich interakcjach pomiędzy pełnosprawnymi członkami klubu a osobą niepełnosprawną, jest tak zwane „realne niezauważanie”, a więc mniej lub bardziej świadome niedostrzeganie w pierwszym rzędzie dysfunkcji ciała danej osoby, a postrzeganie jej przede wszystkim w roli sportowca. $\mathrm{W}$ ten sposób dokonuje się swoista konwersja w sposobie percypowania owej osoby, która oznacza symboliczne zakończenie procesu jej włączania opartego na zasadach partnerstwa w struktury klubu sportowego i grupy tworzącej jej środowisko.

\section{Zakończenie}

Głównym odkryciem dokonanym podczas przeprowadzonych badań było to, że bycie niepełnosprawnym jest społecznie i organizacyjnie tworzone. W niniejszym artykule opisany został proces, przez który „bycie osobą z dysfunkcjami ciała" jest powoli i rutynowo konstruowane w toku wzajemnych interakcji pomiędzy członkami instytucji sportowej. Innymi słowy, badanie ukazało zestaw praktyk organizacyjnych, które przekształciły osobę niepełnosprawną w sportowca z niepełnosprawnością. Niepełnosprawność jako rezultat tych praktyk była związana ze zdarzeniami oraz działaniami, które nie są inherentne dla niepełnosprawności postrzeganej w sposób stereotypowy, wspierany przez dość jeszcze powszechne w naszym społeczeństwie uprzedzenia. Takie potoczne postrzeganie niepełnosprawności, które posiadali członkowie klubu sportowego ze względu na szczególne warunki organizacyjne obecne w instytucji wspierające sport, okazały się być błędnie przypisanymi i przyczyniającymi się do upraszczającej kategoryzacji etykietami.

Na podstawie przeprowadzonych badań i dokonanych analiz zebranego materiału zweryfikowano tezę o tym, że niepełnosprawność (w odniesieniu do cech behawioralnych) była przede wszystkim „procesem”, konceptualnym produktem skonstruowanym w codziennych interakcjach zarówno osób pełnosprawnych między sobą, jak i w stosunku do niepełnosprawnego członka badanego środowiska².

$\overline{2}$ Bardzo podobne postrzeżenia stały się udziałem Sudnowa, który wiele lat temu (1967) w przeprowadzonych przez siebie badaniach na temat społecznej organizacji umierania w szpitalu, pokazał, że śmierć jest najpierw zjawiskiem społecznym, a dopiero później biologicznym. Śmierć pacjenta miała miejsce zanim nastąpił fizyczny zgon, kiedy personel szpitala zadecydował - prawidłowo bądź nie - że pacjent umiera. Rozpoczynano wówczas serię organizacyjnych praktyk przeznaczonych dla umierających, tak że niezwykle trudno było pacjentowi się „przed nimi uchronić”. 
Z punktu widzenia zastosowanego podejścia teoretycznego wyniki badań potwierdzily, że fenomenologicznie zorientowane podejście badawczo-analityczne pozwoliło odkryć te procedury organizacyjne, które mogły być następnie opisane i przedstawione władzom badanej instytucji, trenerom bezpośrednio zaangażowanym $\mathrm{w}$ proces wprowadzania osoby niepełnosprawnej $\mathrm{w}$ działalność sportową, a także pozostałym członkom klubu sportowego.

Badania skłoniły również do wyciągnięcia jednego jeszcze wniosku o charakterze pragmatycznym, a dotyczącym konieczności wyjścia poza prostą (chociaż bardzo użyteczną) perspektywę konstruktywistyczną i przyjęcia takiej perspektywy (społecznej, ideologicznej, politycznej czy kulturowej), która podkreśla dominujące i najbardziej powszechne społeczne reprezentacje zjawiska niepełnosprawności. Dlatego też tak ważne jest pójście w kierunku zmian o charakterze operacyjnym, by rozwiązać praktyczne problemy, nawet wtedy, gdy zasoby są niewystarczające. To uczyniłoby socjologię dyscypliną bardziej użyteczną społecznie niż jest nią ona obecnie.

\section{Bibliografia}

Abberley P. (1987), The concept of oppression and the development of a social theory of disability, "Disability, Handicap and Society", vol. 2(1), s. 5-19.

Balcerzak-Paradowska B. (red.) (2002), Sytuacja osób niepetnosprawnych w Polsce, Raport Instytutu Pracy i Spraw Socjalnych, Centrum Badań i Rozwoju Kształcenia, Warszawa.

Barnes C., Mercer G. (2008), Niepetnosprawność, Warszawa: Sic!, Warszawa.

Barnes C., Geof M. (2004), Disability, Polity Press, London.

Barnes C., Mercer G., Shakespeare T. (1999), Exploring Disability: A Sociological Introduction, Polity Press, Cambridge.

Becker H. (1953), Becoming a Marihuana User, „The American Journal of Sociology”, vol. 59, s. $235-242$.

Becker H. (1963), Outsiders: Studies in the Sociology of Deviance, The Free Press, Glencoe.

Blumer H. (1969), Symbolic Interactionism. Perspective and Method, Prrentice-Hall, Englewood Cliffs, New Jersey.

Bourdieu P., Wacquant L. J. (2001), Zaproszenie do socjologii refleksyjnej, Oficyna Naukowa, Warszawa.

Charmaz K. (1994), Grounded Theory. Objectivist and Constructivist Methods (w:) Handbook of Qualitative Research, N. Denzin, Y. Lincoln (red.), Thousand Oaks, CA, Sage Publications, s. 273-285.

Denzin N. (1972), The Research Act [w:] Symbolic Interaction a reader in social psychology,

J.G. Manis, B.N. Meltze (red.), Allyn\&Bacon, Inc., Boston, s. 76-91.

Finkelstein V. (1993), Disability: a social challenge or an administrative responsibility? [w:] Disabling Barriers - Environments, J. Swain, V. Finkelstein (red.), French, M. Olivier, Sage, Open University, London, s. 106-117.

Finkelstein V. (1980), Attitudes and Disabled People, World Rehabilitation Fund, New York. 
Gilbert N., Mulkay M. (1983), In search of the action [w:] Accounts and Action, N. Gilbert, P. Abell (red.), Gower, Aldershot, s. 8-34.

Glaser B., Strauss A. (1967), The discovery of grounded theory. Strategies for qualitative research, Aldine Publishing Company, Chicago.

Glaser B. (1978), Theoretical Sensitivity, The Sociology Press, San Francisco.

Gobo G. (2008), Crafting Blindness. Its Organizational Construction in a First Grade School, "Qualitative Sociology Review", vol. IV, issue 1, April, s. 92-108.

Goffman E. (2006), Rytuat interakcyjny, Wydawnictwo Naukowe PWN, Warszawa.

Goffman E. (1963), Stigma. Notes on the Management of Spoiled Identity, Harmondsworth, Penguin.

Goffmann E, (1961), Asylums: Essays on Social Situation of Mental Patients and Other Inmates, Anchor Books, Garden City.

Goffman E. (1959), The Presentation of Self in Everyday Life, Doubleday, New York.

Hammersley M., Atkinson P. (2007), Ethnography: Principles in Practice. Third Edition, Routledge, London.

Heritage J. (1984), Garfinkel and Ethnomethodology, Polity Press, Cambridge.

Konecki K. T. (2000), Studia z metodologii badań jakościowych. Teoria ugruntowana, PWN, Warszawa.

Lane H. (1997), Construction of deafness [w:] The Disability Studies Reader, L.J. Davis (red.), Routledge, New York-London, s. 153-171.

Lemerta E. (1951), Social Pathology: A Systematic Approach to the Theory of Sociopathic Behavior, MCGraF-Hill, New York.

Molik B., Morgulec-Adamowicz N., Kosmol A. (2008), Zespołowe gry sportowe osób niepetnosprawnych. Koszykówka na wózkach i rugby na wózkach, AWF w Warszawie, Warszawa.

Oliver M. (1983), Social Work with Disabled People, Macmillan, Basingstoke.

Oliver M. (1990), The Politics of Disablement, Macmillan, London.

Rekowski W., Wilk S. (1997), Rehabilitacja ruchowa [w:] Encyklopedia kultury polskiej XX wieku. Kultura fizyczna, sport, Z. Krawczyk (red.), Instytut Kultury, Warszawa, s. 97-115.

Rosch E. (1978), Principles of Categorization [w:] Cognition and Categorization, E. Rosch, B.B. Lloyd (red.), Erlbaum, Hillsdale, New Jersey, s. 28-48.

Rosch E. (1973), On the internal structure of perceptual and semantic categories [w:] Cognitive development and the Acquisition of Language, T.E. Moore (red.), Academic Press, New York, s. 111-144.

Sacks H. (1972), On the analysability of stories by children (w:) Directions in Sociolinguistics, J. Gumperz, D. Hymes (red.), Holt, Rinehart \& Winston, New York, s. 325-345.

Sobiecka J. (2013), Wizerunek polskiego paraolimpijczyka, AWF, Kraków.

Strauss A., Corbin J. (1990), Basics of Qualitative Research. Grounded Theory Procedures and Techniques, Sage, London.

Strauss A. L. (1959), Mirrors and Masks. The Search for Identity, Transaction Publishers, New Brunswick, London.

Sudnow D, (1967), Passing On. The Social Organization of Dying, Prentice Hall, Englewood Cliffs.

Swain J., Oliver M., French S., Finklestein V. (red) (1993), Disabling Barriers: Enabling Environments, Sage, London. 
Tasiemski T., Koper M. (2013), Miejsce sportu w procesie rehabilitacji osób niepetnosprawnych fizycznie, „Niepełnosprawność - zagadnienia, problemy, rozwiązania”, nr 3(8), s. 111-134. Uramowska-Żyto B. (2010), Socjologiczne koncepcje zdrowia i choroby [w:] Socjologia medycyny. Podejmowane problemy, kategorie analizy, A. Ostrowska (red.), Wydawnictwo IFiS PAN, Warszawa.

WHO (1980), International Classification of Impairments Disabilities and Handicaps, World Health Organization, Geneva. 